\title{
Communication \\ Fabrication of a Solution-Processed White Light Emitting Diode Containing a Single Dimeric Copper(I) Emitter Featuring Combined TADF and Phosphorescence
}

\author{
Gang Cheng ${ }^{1,2,3, *}$, Dongling Zhou ${ }^{1}$, Uwe Monkowius ${ }^{4, *}$ and Hartmut Yersin ${ }^{5, *}$ \\ 1 State Key Laboratory of Synthetic Chemistry, Department of Chemistry, The University of Hong Kong, \\ Pokfulam Road, Hong Kong, China; dlzhou@connect.hku.hk \\ 2 Hong Kong Quantum AI Lab Limited, 17 Science Park West Avenue, Pak Shek Kok, Hong Kong, China \\ 3 HKU Shenzhen Institute of Research and Innovation, Shenzhen 518053, China \\ 4 School of Education, Chemistry, Johannes Kepler University Linz, Altenbergerstr. 69, A-4040 Linz, Austria \\ 5 Institut für Physikalische Chemie, Universität Regensburg, D-93053 Regensburg, Germany \\ * Correspondence: ggcheng@hku.hk (G.C.); uwe.monkowius@jku.at (U.M.); hartmut.yersin@ur.de (H.Y.)
}

\section{check for}

updates

Citation: Cheng, G.; Zhou, D.; Monkowius, U.; Yersin, H.

Fabrication of a Solution-Processed

White Light Emitting Diode

Containing a Single Dimeric

Copper(I) Emitter Featuring

Combined TADF and

Phosphorescence. Micromachines 2021,

12, 1500. https://doi.org/10.3390/

mi12121500

Academic Editor: Aiqun Liu

Received: 6 November 2021

Accepted: 26 November 2021

Published: 30 November 2021

Publisher's Note: MDPI stays neutral with regard to jurisdictional claims in published maps and institutional affiliations.

Copyright: (c) 2021 by the authors. Licensee MDPI, Basel, Switzerland. This article is an open access article distributed under the terms and conditions of the Creative Commons Attribution (CC BY) license (https:/ / creativecommons.org/licenses/by/ $4.0 /)$.

\begin{abstract}
Luminescent copper(I) complexes showing thermally activated delayed fluorescence (TADF) have developed to attractive emitter materials for organic light emitting diodes (OLEDs). Here, we study the brightly luminescent dimer $\mathrm{Cu}_{2} \mathrm{Cl}_{2}(\mathrm{P} \cap \mathrm{N})_{2}(\mathrm{P} \cap \mathrm{N}=$ diphenylphosphanyl-6methyl-pyridine), which shows both TADF and phosphorescence at ambient temperature. A solution-processed OLED with a device structure ITO/PEDOT:PSS/PYD2: $\mathrm{Cu}_{2} \mathrm{Cl}_{2}(\mathrm{P} \cap \mathrm{N})_{2} / \mathrm{DPEPO}$ $(10 \mathrm{~nm}) / \mathrm{TPBi}(40 \mathrm{~nm}) / \mathrm{LiF}(1.2 \mathrm{~nm}) / \mathrm{Al}(100 \mathrm{~nm})$ shows warm white emission with moderate external quantum efficiency (EQE). Methods for EQE increase strategies are discussed.
\end{abstract}

Keywords: dimeric copper(I) complexes; $\mathrm{P} \cap \mathrm{N}$ phosphine ligands; combined thermally activated delayed fluorescence and phosphorescence; thermally activated delayed fluorescence (TADF); combined singlet and triplet harvesting; organic light emitting diodes (OLEDs); white emission; white light emitting OLED (WOLED)

\section{Introduction}

Emerging new display and lighting technologies have considerably stimulated research efforts in the development of new luminescent materials. Organic light emitting diodes (OLEDs) use tailored emitter molecules, which efficiently harvest both singlet and triplet excitons formed in the emission layer at a ratio of 1:3 due to simple spin statistic considerations [1]. It was recognized early that phosphorescent heavy/noble metal complexes can fulfill this requirement because of efficient intersystem crossing (ISC) processes facilitated by the high spin-orbit coupling (SOC) induced by the metal center. This wellestablished strategy is known as triplet harvesting, because the emission stems from the lowest triplet state $\mathrm{T}_{1}$. It has been shown that OLEDs using such complexes can exploit up to $100 \%$ of all formed excitons leading to $100 \%$ internal quantum efficiency (IQE) [2-6]. Nevertheless, this concept comes with the prize of using expensive and rare noble metals like iridium or platinum. As only a very small amount of these noble metals per $\mathrm{m}^{2}$ display area are needed for modern OLEDs, the price per one display unit is unimportant and therefore, use of these metals seems to be acceptable. However, just because of the low noble metal content, recycling of the metal is either not possible or economically not viable. Therefore, one must assume that these metals are irretrievably lost and will be evenly distributed among the Earth's ecosystem as with many other valuable (or persistent) materials of widely used consumer products. As soon as the OLED technology will dominate the display and lighting area, even such small amounts will sum up to a considerable consumption of these precious metals, which thus would be lost for other important applications, such as catalytic processes in the chemical industry [7]. 
Therefore, similar to the trend in catalysis, increasing research activities are focused on the replacement of noble metals by non-precious and abundant metals or even by purely organic compounds while still maintaining a high efficiency of the OLEDs [8]. The related exciton issue is addressed by designing emitter molecules with small singlettriplet splittings $\Delta \mathrm{E}\left(\mathrm{S}_{1}-\mathrm{T}_{1}\right)$, being one essential condition for fast and efficient reverse intersystem crossing (rISC) $T_{1} \rightarrow S_{1}$ from the triplet state $T_{1}$ to the excited singlet state $S_{1}$ which ideally shows efficient $S_{1} \rightarrow S_{0}$ fluorescence. Although long known as thermally activated delayed fluorescence (TADF) or E-type fluorescence [9], use of this process for OLEDs was proposed only in $2006 / 2008$ by Yersin et al. [10] and was designated as singlet harvesting, because the luminescence of the TADF emitters stems from the lowest excited singlet state. For the first time, this mechanism was exploited for OLED application in 2010 [11]. Besides other metals, particularly copper(I) complexes have proven to feature efficient TADF due to the distinct metal-to-ligand charge transfer (MLCT) character of their emissive states [12-32]. Additionally, a large number of purely organic compounds have been investigated, especially, by the Adachi group [33-38]. These molecules feature required photophysical properties, such as high emission quantum yields and relatively fast emission decay times lying in the range of a few $\mu$ s and can lead to high external quantum efficiencies (EQE) in OLEDs [39-44]. Very recently, almost "zero-gap compounds" have been presented that also allow for $100 \%$ exciton use, based on a mechanism that is designated as direct singlet harvesting $[45,46]$. Using this mechanism, that is, applying the specifically designed molecules as OLED emitters, sub-micro second decay times can easily be achieved [45].

It has been shown that emissive copper(I) complexes sometimes do not only emit via the TADF process, but additionally feature phosphorescence [25,47-62]. The Cu(I) materials applied for many of these investigations are based on a patent filed almost one decade ago [63]. This combination of singlet and triplet emission shortens the emission decay time. These complexes can be regarded as both singlet and triplet harvesting materials, and thus are interesting for application in OLEDs. Indeed, corresponding device studies have already been reported [64,65].

In recent studies, we have presented a series of di-nuclear copper(I) complexes with bridging $\mathrm{P} \cap \mathrm{N}$ phosphane ligands (whereas the nitrogen atom is part of a pyridine-type moiety) and discussed their photophysical properties in detail [47-50]. One of these materials, $\mathrm{Cu}_{2} \mathrm{Cl}_{2}(\mathrm{P} \cap \mathrm{N})_{2}$ (Figure 1), shows remarkably high emission quantum yield at a moderate emission decay time $\left(\varphi_{\mathrm{PL}}=92 \%, \tau=8.3 \mu \mathrm{s}\right)$ even at ambient temperature as powder material. This compound was not yet investigated in opto-electronic devices. Accordingly, it is the subject of this investigation to study the compound's properties in solution-processed OLEDs, and also to contribute to a better understanding of such $\mathrm{Cu}(\mathrm{I})$ based devices. Interestingly, its broad emission spectrum enables us to fabricate white light emitting OLEDs (WOLEDs) by using $\mathrm{Cu}_{2} \mathrm{Cl}_{2}(\mathrm{P} \cap \mathrm{N})_{2}$ as a single emitter. Compared to those manufactured with multiple emitters, WOLEDs with a single emitter have the merits of easy fabrication, low cost, and, more importantly, of avoiding the issue of color aging [66].<smiles></smiles>

Figure 1. Di-nuclear $\mathrm{Cu}(\mathrm{I})$ complex, $\mathrm{Cu}_{2} \mathrm{Cl}_{2}(\mathrm{P} \cap \mathrm{N})_{2}$ featuring both TADF and phosphorescence [48]. 


\section{Photophysical Background of $\mathrm{Cu}_{2} \mathrm{Cl}_{\mathbf{2}}(\mathrm{P} \cap \mathrm{N})_{2}$}

$\mathrm{Cu}_{2} \mathrm{Cl}_{2}(\mathrm{P} \cap \mathrm{N})_{2}$ was synthesized as described in ref. [48]. It represents one of the first compounds for which an ambient temperature emission has been reported that consists of combined phosphorescence and TADF [48]. In particular, the material shows $\approx 20 \%$ direct $\mathrm{T}_{1} \rightarrow \mathrm{S}_{0}$ phosphorescence and $\approx 80 \%$ delayed $\mathrm{S}_{1} \rightarrow \mathrm{S}_{0}$ fluorescence. This is a consequence of the relatively high spin-orbit coupling (SOC) experienced by the $\mathrm{T}_{1}$ state. The efficiency of SOC is also displayed in a large zero-field splitting of this triplet state [48, and compare [67]. Both states, $\mathrm{T}_{1}$ and $\mathrm{S}_{1}$, stem from the HOMO $\rightarrow$ LUMO transition of metal-to-ligand charge transfer (MLCT) character. Hence, the states represent ${ }^{1} \mathrm{MLCT}\left(\mathrm{S}_{1}\right)$ and ${ }^{3} \mathrm{MLCT}\left(\mathrm{T}_{1}\right)$ states. Both are in fast thermal equilibrium at ambient temperature. Due to the occurrence of two separate decay paths with decay rates of $\mathrm{k}\left(\mathrm{T}_{1} \rightarrow \mathrm{S}_{0}\right.$, phosphorescence $)=2.4 \times 10^{4} \mathrm{~s}^{-1}$ (formally $42 \mu \mathrm{s}$ ) and $\mathrm{k}\left(\mathrm{S}_{1} \rightarrow \mathrm{S}_{0}, \mathrm{TADF}\right)=9.1 \times 10^{4} \mathrm{~s}^{-1}$ (formally $11 \mu \mathrm{s}$ ), the overall decay time is reduced from the TADF-only decay time of 11 to $8.3 \mu$ s [48].

As neat powder, the material shows an emission quantum yield of $\Phi_{\mathrm{PL}}=92 \%$ with an emission peak maximum at $\lambda_{\max }=485 \mathrm{~nm}$. However, if doped with $8 \mathrm{wt} \%$ in di(9H-carbazol-9-yl)pyridine (PYD2) (see next section), $\Phi_{\mathrm{PL}}$ decreases to $27 \%$ (in PMMA (poly(methyl methacrylate)) to $\approx 8 \%$ ) and the peak maximum red-shifts to $544 \mathrm{~nm}$ (Table 1). Such a behavior is frequently found for $\mathrm{Cu}(\mathrm{I})$ complexes and is ascribed to a flattening distortion in the excited MLCT state [68-70]. This process is connected with an energy stabilization of the excited states. Accordingly, the emission is red shifted. Besides, a polarity change of the emitter environment might also play a role $[45,71]$. It has been shown that the flattening processes are less distinct in rigid crystalline environments than in softer matrices, such as many polymers or PYD2 [14,51]. Moreover, the geometry distortion in the excited states usually results in larger Franck-Condon (FC) factors between the lower energy vibrational wavefunctions of the involved excited state with higher energy vibrational wavefunctions of the ground state. These FC factors strongly govern the non-radiative decay. Hence, their increase induces a reduction of the emission quantum yield [72]. Indeed, $\Phi_{\mathrm{PL}}$ decreases from $92 \%$ in crystalline environment to $27 \%$ in the less rigid PYD2 matrix (Table 1). Nevertheless, it is attractive to study this emitter material, giving white light luminescence, in a solution-processed OLED.

Table 1. Photophysical data of $\mathrm{Cu}_{2} \mathrm{Cl}_{2}(\mathrm{P} \cap \mathrm{N})_{2}$ measured at $300 \mathrm{~K}$.

\begin{tabular}{|c|c|c|c|c|c|c|}
\hline $\begin{array}{l}\text { Photophys. } \\
\text { Data }\end{array}$ & $\begin{array}{l}\text { Neat } \\
\text { Powder (a) }\end{array}$ & $\begin{array}{l}\text { Doped in } \\
\text { PYD2 (b) }\end{array}$ & $\begin{array}{l}\text { Doped in } \\
\mathrm{mCP}^{(\mathrm{b}),(\mathrm{c})}\end{array}$ & $\begin{array}{l}\text { Doped in } \\
\text { PVK }^{(b),(c)}\end{array}$ & $\begin{array}{l}\text { Doped in } \\
\text { TCTA }^{(b),(c)}\end{array}$ & $\begin{array}{l}\text { Doped in } \\
\text { CBP }{ }^{(b),(c)}\end{array}$ \\
\hline$\lambda_{\max }(\mathrm{d})$ & $485 \mathrm{~nm}$ & $544 \mathrm{~nm}$ & $535 \mathrm{~nm}$ & $545 \mathrm{~nm}$ & $542 \mathrm{~nm}$ & $537 \mathrm{~nm}$ \\
\hline$\varphi_{\mathrm{PL}}{ }^{(\mathrm{e})}$ & $92 \%$ & $27 \%$ & $20 \%$ & $11 \%$ & $10 \%$ & $13 \%$ \\
\hline$\tau^{(\mathrm{e})}$ & $8.3 \mu \mathrm{s}$ & $3.1 \mu \mathrm{s}$ & $5.5 \mu \mathrm{s}$ & $3.2 \mu \mathrm{s}$ & $4.3 \mu \mathrm{s}$ & $2.8 \mu \mathrm{s}$ \\
\hline$\Delta\left(\mathrm{S}_{1}-\mathrm{T}_{1}\right)^{(\mathrm{f})}$ & $\begin{array}{l}930 \mathrm{~cm}^{-1} \\
(115 \mathrm{meV})\end{array}$ & & & & & \\
\hline
\end{tabular}

(a) Data from ref. [48]. (b) This work, doping concentration $8 \mathrm{wt} \%$. (c) The various host materials are specified in the Appendix A.

(d) Emission maxima. (e) Photoluminescence quantum yield and emission decay time, respectively. ${ }^{(\mathrm{f})}$ TADF activation energy.

\section{Solution-Processed WOLEDs with $\mathrm{Cu}_{2} \mathrm{Cl}_{2}(\mathrm{P} \cap \mathrm{N})_{2}$ as a Single Emitter}

Photoluminescence quantum yield (PLQY) and emission decay time of $\mathrm{Cu}_{2} \mathrm{Cl}_{2}(\mathrm{P} \cap \mathrm{N})_{2}$ in various thin films were measured and the results are summarized in Table 1. PLQY of $27 \%$ in PYD2 is the highest yield among the hosts that are frequently applied in solution-processed OLEDs. In fact, PYD2 has been proved as a suitable host for $\mathrm{Cu}$ complexes in solution-processed OLEDs [72,73]. Based on this result, solution processed WOLEDs were fabricated using $\mathrm{Cu}_{2} \mathrm{Cl}_{2}(\mathrm{P} \cap \mathrm{N})_{2}$ as a single emitter and PYD2 as host material for the emissive layer (EML). As shown in Figure 2, the device structure was ITO/PEDOT:PSS (50 nm)/PYD2: $\mathrm{Cu}_{2} \mathrm{Cl}_{2}(\mathrm{P} \cap \mathrm{N})_{2}(60 \mathrm{~nm}) / \mathrm{DPEPO}(10 \mathrm{~nm}) / \mathrm{TPBi}(40 \mathrm{~nm}) / \mathrm{LiF}$ $(1.2 \mathrm{~nm}) / \mathrm{Al}(100 \mathrm{~nm})$. The layer of poly(3,4-ethylenedioxythiophene) polystyrene sulfonate (PEDOT:PSS) was used between the ITO anode and the EML as a hole-injection layer. The layers bis[2-(diphenylphosphino)phenyl]ether oxide (DPEPO) and 1,3,5-tris(1-phenyl-1H- 
benzo[d]imidazol-2-yl)benzene (TPBi) function as hole/exciton blocking and electron transporting materials, respectively. As shown in Figure 2, the low-lying LUMO of TPBi facilitates the electron-transporting while the wide band gap of DPEPO can effectively confine excitons inside the EML. $\mathrm{Cu}_{2} \mathrm{Cl}_{2}(\mathrm{P} \cap \mathrm{N})_{2}$ was used as a single emitting dopant in the EML with various concentrations ranging from 2 to $8 \mathrm{wt} \%$. Device performances are depicted in Figure 3, and key data are summarized in Table 2. At a lower concentration of $2 \mathrm{wt} \%$, distinct emission from the PYD2 host peaking at $\approx 400 \mathrm{~nm}$ (Figure 3a) suggests insufficient energy transfer from the host to the emitter, leading to relatively low efficiency, as displayed in Figure 3b. With increasing dopant concentration, the host emission gradually vanishes, and accordingly the efficiency is improved. In addition, as depicted in Figure $3 c, d$, both current density and luminance significantly decrease with increasing dopant concentration at a given driving voltage, suggesting that charge-trapping could play an important role in these OLEDs [74]. As shown in Figure 2, the high-lying HOMO of $\mathrm{Cu}_{2} \mathrm{Cl}_{2}(\mathrm{P} \cap \mathrm{N})_{2}$ could effectively trap holes injected from the PEDOT:PSS layer. The efficiency of $\mathrm{Cu}_{2} \mathrm{Cl}_{2}(\mathrm{P} \cap \mathrm{N})_{2}$-based devices is limited by the relatively low PLQY of thin films, which is slightly dependent on the dopant concentration. With concentration increase from 4 to $8 \mathrm{wt} \%$, PLQY increases from $19 \%$ to $27 \%$ (at $\lambda_{\mathrm{exc}}=360 \mathrm{~nm}$ ), probably because the increased doping concentration leads to an increase of the environment rigidity. Nonetheless, the simple device structure and the ultra-broad electro-luminescence (EL) spectra with full width at half maximum (FWHM) of $153 \mathrm{~nm}$ make these studies attractive. One obtains a yellowish white emission with CIE coordinates of $(0.38,0.49)$ and a color rendering index (CRI) of 64 in the device with $8 \mathrm{wt} \%$ of $\mathrm{Cu}_{2} \mathrm{Cl}_{2}(\mathrm{P} \cap \mathrm{N})_{2}$. With the participation of the host emission, the device with $2 \mathrm{wt} \% \mathrm{Cu}_{2} \mathrm{Cl}_{2}(\mathrm{P} \cap \mathrm{N})_{2}$ gives an improved white color with CIE coordinates of $(0.38,0.45)$ and CRI of 72 . By improving the PLQY of the films and by further optimizing the device structure, dimeric copper(I) emitters featuring combined TADF and phosphorescence may find wide application in future low-cost WOLEDs.

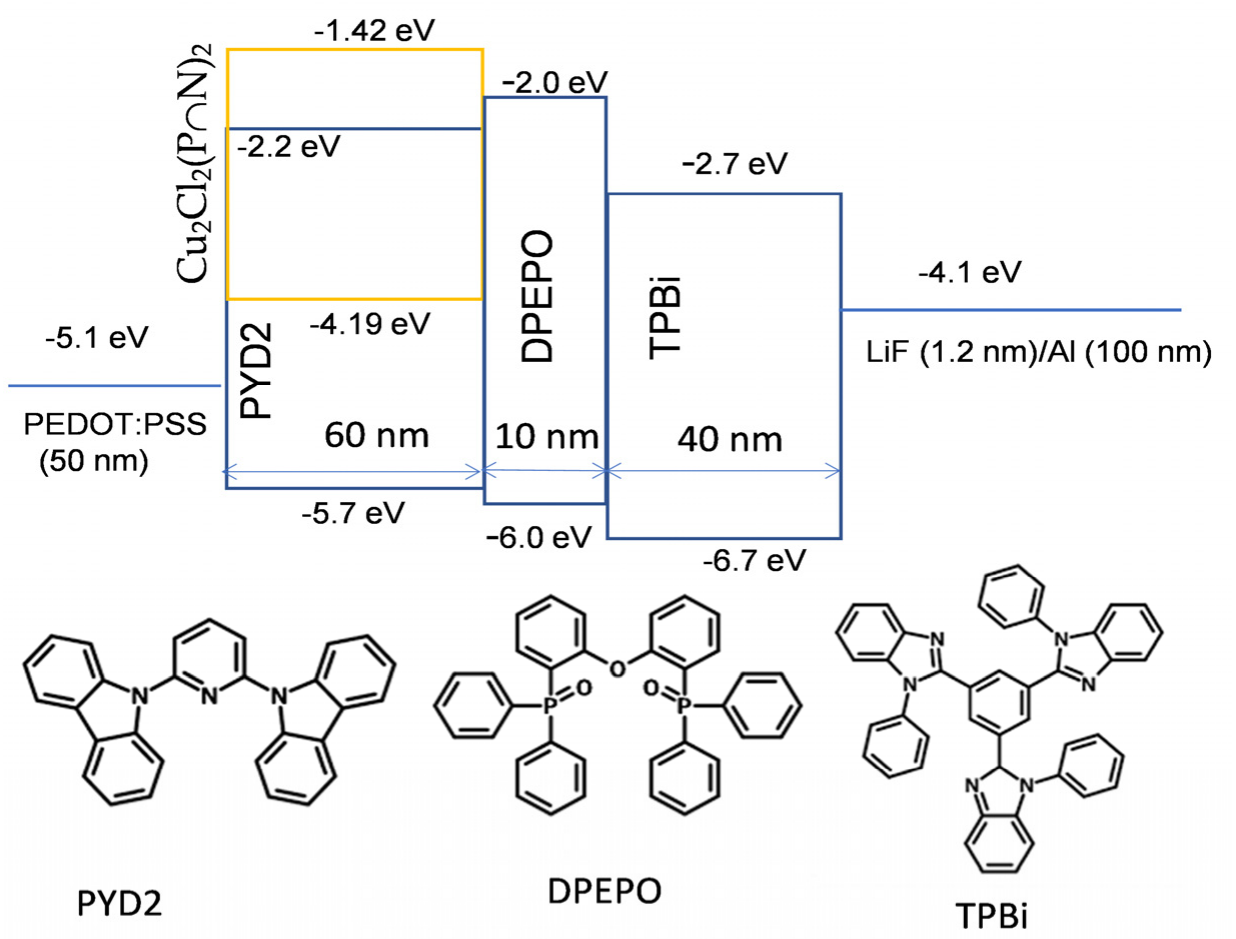

Figure 2. Schematic diagram of the OLEDs, showing the respective energy levels, layer thicknesses, and chemical structures of the organic materials used for the device. The energy levels of $\mathrm{Cu}_{2} \mathrm{Cl}_{2}(\mathrm{P} \cap \mathrm{N})_{2}$ were measured by an electrochemical method and those of other materials were extracted from the literature [72,73,75-77]. 

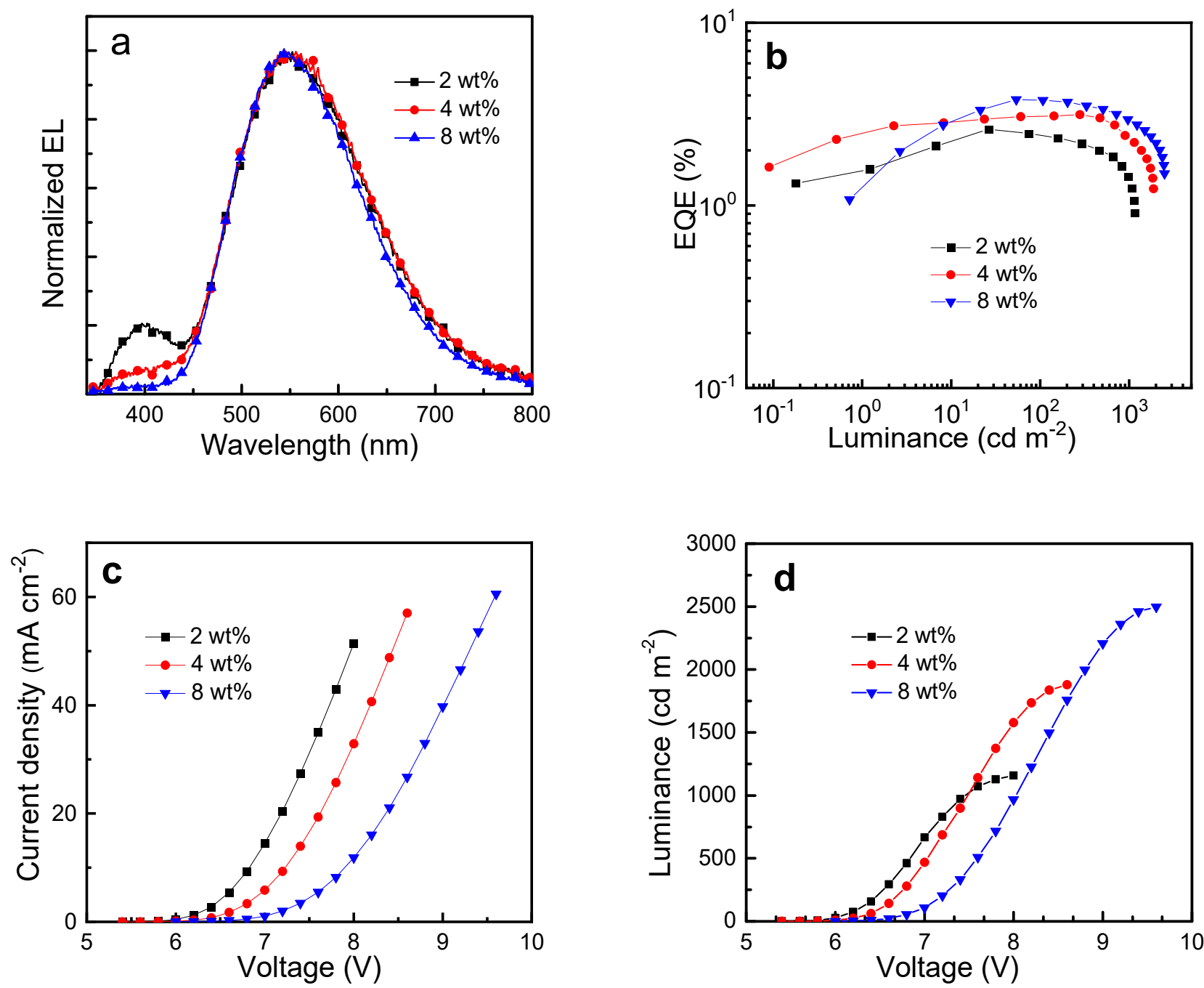

Figure 3. Characteristics of solution-processed devices according to Figure 2 based on $\mathrm{Cu}_{2} \mathrm{Cl}_{2}(\mathrm{P} \cap \mathrm{N})_{2}$ luminescent compounds with concentrations of 2, 4, and $8 \mathrm{wt} \%$ in PYD2 host films. (a) Normalized EL spectra at $1000 \mathrm{~cd} \mathrm{~m}{ }^{-2}$, (b) EQE vs. luminance (c) current density vs. voltage, and (d) luminance vs. voltage characteristics.

Table 2. Key performances of OLEDs with $\mathrm{Cu}_{2} \mathrm{Cl}_{2}(\mathrm{P} \cap \mathrm{N})_{2}$.

\begin{tabular}{|c|c|c|c|c|c|c|c|c|c|c|}
\hline \multirow{2}{*}{$\begin{array}{c}\text { Concentration } \\
(w t \%)\end{array}$} & \multirow{2}{*}{$\begin{array}{c}\mathrm{L}^{\text {(a) }} \\
\left(\mathrm{cd} \mathrm{m}^{-2}\right)\end{array}$} & \multicolumn{2}{|c|}{$\begin{array}{c}\mathrm{CE}^{(\mathrm{b})} \\
\left(\mathrm{cd} \mathrm{A}^{-1}\right)\end{array}$} & \multicolumn{2}{|c|}{ 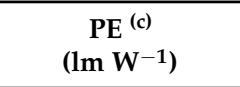 } & \multicolumn{2}{|c|}{$\begin{array}{c}\mathrm{EQE}_{(\%)}^{(d)} \\
(\%)\end{array}$} & \multirow[t]{2}{*}{$\begin{array}{c}\mathrm{CIE}^{(e)} \\
(x, y)\end{array}$} & \multirow[t]{2}{*}{$\begin{array}{c}\text { FWHM }^{(\mathrm{f})} \\
(\mathrm{nm})\end{array}$} & \multirow[t]{2}{*}{$\mathrm{CRI}^{(\mathrm{g})}$} \\
\hline & & Max & $\begin{array}{l}\text { at } 1000 \mathrm{~cd} \\
\mathrm{~m}^{-2}\end{array}$ & $\operatorname{Max}$ & $\begin{array}{l}\text { at } 1000 \\
\text { cd } m^{-2}\end{array}$ & Max & $\begin{array}{l}\text { at } 1000 \mathrm{~cd} \\
\mathrm{~m}^{-2}\end{array}$ & & & \\
\hline 2 & 1160 & 6.48 & 3.54 & 3.39 & 1.48 & 2.61 & 1.42 & $0.38,0.45$ & 162 & 72 \\
\hline 4 & 1880 & 8.39 & 6.24 & 4.01 & 2.71 & 3.14 & 2.31 & $0.38,0.48$ & 159 & 69 \\
\hline 8 & 2500 & 10.5 & 8.15 & 4.25 & 3.20 & 3.80 & 2.95 & $0.38,0.49$ & 153 & 64 \\
\hline
\end{tabular}

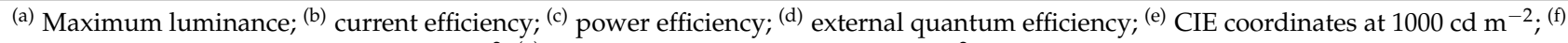
full width at half maximum at $1000 \mathrm{~cd} \mathrm{~m}^{-2}$; (g) color rendering index at $1000 \mathrm{~cd} \mathrm{~m}^{-2}$.

\section{Conclusions}

In this study, we report on OLED characteristics of the $\mathrm{Cu}(\mathrm{I})$ dimer $\mathrm{Cu}_{2} \mathrm{Cl}_{2}(\mathrm{P} \cap \mathrm{N})_{2}$ that features both phosphorescence and TADF at ambient temperature. With the device structure described in Figure 2, we determined an external quantum efficiency of EQE $=3.80$ showing warm white emission (CIE coordinates $(0.38,0.49))$. This EQE value is lower than expected from the high photoluminescence quantum yield of $92 \%$ found for the powder material. However, doping $\mathrm{Cu}_{2} \mathrm{Cl}_{2}(\mathrm{P} \cap \mathrm{N})_{2}$ in the less rigid PYD2 host material allows for 
more distinct geometry reorganization upon excitation than for the complex in the powder environment. As a consequence, the host with $8 \mathrm{wt} \%$ doping concentration exhibits only $\varphi_{\mathrm{PL}}=27 \%$ photoluminescence. If we formally normalize EQE to $\varphi_{\mathrm{PL}}=100 \%$, we find $\mathrm{EQE}($ normalized $)=14 \%$. This shows that more efficient devices based on $\mathrm{Cu}(\mathrm{I})$ emitters can be obtained, if the emitter's molecular structure and the host environment can be designed distinctly more rigidly (compare ref. [51]).

\section{Patents}

Parts of this work are related to (i) Yersin, H.; Monkowius, U. Komplexe mit kleinen Singulett-Triplett-Energie-Abständen zur Verwendung in opto-elektronischen Bauteilen (Singulett-Harvesting-Effekt). German Patent DE102008033563 A1, 2008, and (ii) Monkowius, U.; Hofbeck, T.; Yersin, H. Singulett-Harvesting mit zweikernigen Kupfer(I)-Komplexen für opto-elektronische Vorrichtungen. German Patent DE102011080240 A1, 2013.

Author Contributions: Conceptualization, G.C., U.M. and H.Y.; methodology, G.C., D.Z., U.M. and H.Y.; writing—original draft preparation, G.C., U.M. and H.Y.; writing—review and editing, G.C., U.M. and H.Y.; visualization, G.C., D.Z., U.M. and H.Y.; material synthesis, U.M.; device fabrication, G.C. All authors have read and agreed to the published version of the manuscript.

Funding: This research was funded by the Major Program of Guangdong Basic and Applied Research (2019B030302009), the Basic Research Program of Shenzhen (JCYJ20170818141858021 and JCYJ20200109150414471), and Hong Kong Quantum AI Lab Limited.

Conflicts of Interest: The authors declare that they do not have any competing financial interests or personal relationships that could have appeared to influence the work reported in this paper.

\section{Appendix A}

Materials: $\mathrm{Cu}_{2} \mathrm{Cl}_{2}(\mathrm{P} \cap \mathrm{N})_{2}$ was synthesized as described in ref. [48]. PEDOT:PSS [poly(3,4-ethylenedioxythiophene):poly(styrene sulfonic acid)] (Clevios P AI 4083) was purchased from Heraeus; PYD2, DPEPO, TPBi, poly(9-vinylcarbazole) (PVK), 1,3-Bis(carbazol9-yl)benzene (mCP), 4,4',4-Tris(carbazol-9-yl)triphenylamine (TCTA), 4,4'-Bis(carbazol-9yl)biphenyl (CBP), and LiF from Luminescence Technology Corp; Aluminum pellets from Kurt J. Lesker. All materials were used as received.

Photophysical measurement (see Table A1): Thin-film samples of $\mathrm{Cu}_{2} \mathrm{Cl}_{2}(\mathrm{P} \cap \mathrm{N})_{2}$ doped in PYD2, mCP, PVK, TCTA, and CBP, respectively, were prepared by drop-cast from a chlorobenzene solution containing $\mathrm{Cu}_{2} \mathrm{Cl}_{2}(\mathrm{P} \cap \mathrm{N})_{2}(8 \mathrm{wt} \%)$. The solvent was evaporated at $80{ }^{\circ} \mathrm{C}$ and translucent films were obtained. PLQYs of these thin-film samples were measured with the Hamamatsu C11347 Quantaurus-QY absolute PL quantum yield measurement system. Emission lifetime measurements were performed on a Quanta Ray GCR 150-10 pulsed Nd:YAG laser system.

Table A1. Electrochemical properties of $\mathrm{Cu}_{2} \mathrm{Cl}_{2}(\mathrm{P} \cap \mathrm{N})_{2}$.

\begin{tabular}{ccc}
\hline & $E_{\text {ox }}$ and $E_{\text {red }}(\mathrm{V}){ }^{(\mathbf{a})}$ & $E_{\text {HOMO }}$ and $E_{\text {LUMO }}(\mathrm{eV})$ \\
\hline $\mathrm{Cu}_{2} \mathrm{Cl}_{2}(\mathrm{P} \cap \mathrm{N}){ }_{2}$ & $0.504 ;-2.488$ & $-4.91 ;-1.42$ \\
\hline
\end{tabular}

(a) Values obtained from differential pulse voltammetry measurements which were carried out in acetonitrile with $0.1 \mathrm{~mol} \cdot \mathrm{dm}^{-3}\left[n \mathrm{Bu}_{4} \mathrm{~N}\right] \mathrm{PF}_{6}$ as supporting electrolyte and saturated calomel electrode (SCE) as the reference electrode with a scan rate of $100 \mathrm{mV} \cdot \mathrm{s}^{-1}$. Potentials reported here versus SCE. ${ }^{(b)}$ The HOMO and LUMO energy levels were estimated based on the equations of $E_{\mathrm{HOMO}}=-\left(1.15 \times E_{\mathrm{ox}}+4.79\right) \mathrm{eV}, E_{\mathrm{LUMO}}=-\left(1.18 \times E_{\mathrm{red}}+4.83\right)$ $\mathrm{eV}[19,78]$; the potential $E_{\mathrm{ox}}$ of ferrocene is $0.40 \mathrm{~V}$.

Fabrication process of solution-processed OLEDs: An aqueous solution of PEDOT:PSS was spin-coated onto the cleaned ITO coated glass substrate and baked at $120{ }^{\circ} \mathrm{C}$ for $20 \mathrm{~min}$ to remove the residual water solvent in a clean room. Afterwards, the mixture of PYD2 and the emitting dopant in chlorobenzene was spin-coated atop the PEDOT:PSS layer inside the glove box. After annealing at $70{ }^{\circ} \mathrm{C}$ for $30 \mathrm{~min}$, all devices were subsequently transferred into a Kurt J. Lesker SPECTROS vacuum deposition system without exposing to air. In the vacuum chamber, organic materials of DPEPO and TPBi were thermally deposited in 
sequence at a rate of $\sim 0.5 \mathrm{~nm} \mathrm{~s}^{-1}$. Finally, $\operatorname{LiF}(1.2 \mathrm{~nm})$ and $\mathrm{Al}(100 \mathrm{~nm})$ were thermally deposited at rates of 0.03 and $0.2 \mathrm{~nm} \mathrm{~s}^{-1}$, respectively.

Characterization of OLEDs: Current density-brightness-voltage characteristics, EL spectra, and EQE of EL device were obtained by using a Keithley 2400 source-meter and an absolute external quantum efficiency measurement system (C9920-12, Hamamatsu Photonics).

\section{References}

1. Helfrich, W.; Schneider, W.G. Transients of volume-controlled current and of recombination radiation in anthracene. J. Chem. Phys. 1966, 44, 2902-2909. [CrossRef]

2. Yersin, H. Highly Efficient OLEDs with Phosphorescent Materials; Wiley-VCH Verlag: Weinheim, Germany, 2008. [CrossRef]

3. Brütting, W.; Adachi, C. Physics of Organic Semiconductors; Wiley-VCH Verlag: Weinheim, Germany, 2012.

4. Baldo, M.A.; O’Brien, D.F.; You, Y.; Shoustikov, A.; Sibley, S.; Thompson, M.E.; Forrest, S.R. Highly efficient phosphorescent emission from organic electroluminescent devices. Nature 1998, 395, 151-154. [CrossRef]

5. Adachi, C.; Baldo, M.A.; Thompson, M.E.; Forrest, S.R. Nearly 100\% internal phosphorescence efficiancy in an organic lightemitting device. J. Appl. Phys. 2001, 90, 5048-5051. [CrossRef]

6. Yersin, H. Triplet Emitters for OLED Applications. Mechanisms of Exciton Trapping and Control of Emission Properties. Top. Curr. Chem. 2004, 241, 1-26. [CrossRef]

7. Minke, C.; Suermann, M.; Bensmann, B.; Hanke-Rauschenbach, R. Is iridium demand a potential bottleneck in the realization of large-scale PEM water electrolysis? Int. J. Hydrog. Energy 2021, 46, 23581-23590. [CrossRef]

8. Li, X.; Xie, Y.; Li, Z. Diversity of Luminescent Metal Complexes in OLEDs: Beyond Traditional Precious Metals. Chem. Asian J. 2021, 16, 2817-2829. [CrossRef]

9. Parker, C.A.; Hatchard, C.G. Triplet-singlet emission in fluid solutions. Phosphorescence of eosin. Trans. Faraday Soc. 1961, 57, 1894-1904. [CrossRef]

10. Yersin, H.; Monkowius, H. Komplexe mit Kleinen Singulett-Triplett Energie-Abständen zur Verwendung in Opto-Elektronischen Bauteilen (Singulett Harvesting Effekt). German Patent DE102008033563 A1, 17 July 2008.

11. Deaton, J.C.; Switalski, S.C.; Kondakov, D.Y.; Young, R.H.; Pawlik, T.D.; Giesen, D.J.; Harkins, S.B.; Miller, A.J.M.; Mickenberg, S.F.; Peters, J.C. E-type delayed fluorescence of a phosphine-supported $\mathrm{Cu}_{2}\left(\mu-\mathrm{NAr}_{2}\right)_{2}$ diamond core: Harvesting singlet and triplet excitons in OLEDs. J. Am. Chem. Soc. 2010, 132, 9499-9508. [CrossRef]

12. Czerwieniec, R.; Yu, J.; Yersin, H. Blue-light emission of $\mathrm{Cu}(\mathrm{I})$ complexes and singlet harvesting. Inorg. Chem. 2011, 50, 8293-8301. [CrossRef]

13. Leitl, M.J.; Zink, D.M.; Schinabeck, A.; Baumann, T.; Volz, D.; Yersin, H. Copper(I) Complexes for Thermally Activated Delayed Fluorescence: From Photophysical to Device Properties. Top. Curr. Chem. 2016, 374, 25-65. [CrossRef]

14. Czerwieniec, R.; Leitl, M.J.; Homeier, H.H.H.; Yersin, H. Cu(I) complexes-Thermally activated delayed fluorescence. Photophysical approach and material design. Coord. Chem. Rev. 2016, 325, 2-28. [CrossRef]

15. Yersin, H. Highly Efficient OLEDs: Materials Based on Thermally Activated Delayed Fluorescence; WILEY-VCH: Weinheim, Germany, 2019.

16. Yersin, H.; Czerwieniec, R.; Shafikov, V.; Suleymanova, A.F. TADF Material Design: Photophysical Background and Case Studies Focusing on $\mathrm{Cu}(\mathrm{I})$ and $\mathrm{Ag}(\mathrm{I})$ Complexes. ChemPhysChem 2017, 18, 3508-3535. [CrossRef] [PubMed]

17. Armaroli, N.; Bolink, H.J. (Eds.) Photoluminescent Materials and Electroluminescent Devices; Topics in Current Chemistry Collections; Springer: Cham, Switzerland, 2017. [CrossRef]

18. Hamze, R.; Peltier, J.L.; Sylvinson, D.; Jung, M.; Cardenas, J.; Haiges, R.; Soleilhavoup, M.; Jazzar, R.; Djurovich, P.I.; Bertrand, G.; et al. Eliminating nonradiative decay in $\mathrm{Cu}(\mathrm{I})$ emitters: $99 \%$ quantum efficiency and microsecond lifetime. Science 2019, 363, 601-606. [CrossRef]

19. Shi, S.; Jung, M.C.; Coburn, C.; Tadle, A.; Sylvinson, M.R.D.; Djurovich, P.I.; Forrest, S.R.; Thompson, M.E. Highly Efficient Photoand Electroluminescence from Two-Coordinate $\mathrm{Cu}(\mathrm{I})$ Complexes Featuring Nonconventional N-Heterocyclic Carbenes. J. Am. Chem. Soc. 2019, 141, 3576-3588. [CrossRef] [PubMed]

20. Romanov, A.S.; Jones, S.T.E.; Gu, Q.; Conaghan, P.J.; Drummond, B.H.; Feng, J.; Chotard, F.; Buizza, L.; Foley, M.; Linnolahti, M.; et al. Carbene metal amide photoemitters: Tailoring conformationally flexible amides for full color range emissions including white-emitting OLED. Chem. Sci. 2020, 11, 435-446. [CrossRef] [PubMed]

21. Föller, J.; Ganter, C.; Steffen, A.; Marian, C.M. Computer-Aided Design of Luminescent Linear N-Heterocyclic Carbene Copper(I) Pyridine Complexes. Inorg. Chem. 2019, 58, 5446-5456. [CrossRef]

22. Dumur, F. Recent advances in organic light-emitting devices comprising copper complexes: A realistic approach for low-cost and highly emissive devices? Org. Electron. 2015, 21, 27-39. [CrossRef]

23. Osawa, M.; Hoshino, M.; Hashimoto, M.; Kawata, I.; Igawa, S.; Yashima, M. Application of three-coordinate copper(I) complexes with halide ligands in organic light-emitting diodes that exhibit delayed fluorescence. Dalton Trans. 2015, 44, 8369-8378. [CrossRef]

24. So, G.K.-M.; Cheng, G.; Wang, J.; Chang, X.; Kwok, C.-C.; Zhang, H.; Che, C.-M. Efficient Color-Tunable Copper(I) Complexes and Their Applications in Solution-Processed Organic Light-Emitting Diodes. Chem. Asian J. 2017, 12, 1490-1498. [CrossRef]

25. Bizzarri, C.; Hundemer, F.; Busch, J.; Bräse, S. Triplet emitters versus TADF emitters in OLEDs: A comparative study. Polyhedron 2018, 140, 51-66. [CrossRef] 
26. Artem'ev, A.V.; Ryzhikov, M.R.; Taidakov, I.V.; Rakhmanova, M.I.; Varaksina, E.A.; Bagryanskaya, I.Y.; Malysheva, S.F.; Belogorlova, N.A. Bright Green-to-Yellow Emitting Cu(I) Complexes Based on Bis(2-Pyridyl)Phosphine Oxides: Synthesis, Structure and Effective Thermally Activated-Delayed Fluorescence. Dalton Trans. 2018, 47, 2701-2710. [CrossRef]

27. Ohara, H.; Kobayashi, A.; Kato, M. Effects of N-Heteroaromatic Ligands on Highly Luminescent Mononuclear Copper(I)-Halide Complexes. Comptes Rendus Chim. 2015, 18, 766-775. [CrossRef]

28. Ohara, H.; Kobayashi, A.; Kato, M. Simple and Extremely Efficient Blue Emitters Based on Mononuclear Cu(I)-Halide Complexes with Delayed Fluorescence. Dalton Trans. 2014, 43, 17317-17323. [CrossRef] [PubMed]

29. Nozaki, K.; Iwamura, M. Highly Emissive $\mathrm{d}^{10}$ Metal Complexes as TADF Emitters with Versatile Structures and Photophysical Properties. In Highly Efficient OLEDs; Yersin, H., Ed.; Wiley-VCH Verlag: Weinheim, Germany, 2018; pp. 61-91. [CrossRef]

30. Arnosti, N.; Brunner, F.; Susic, I.; Keller, S.; Junquera-Hernández, J.M.; Prescimone, A.; Bolink, H.J.; Sessolo, M.; Ortí, E.; Housecroft, C.E.; et al. Remote Modification of Bidentate Phosphane Ligands Controlling the Photonic Properties in Their Complexes: Enhanced Performance of $\left[\mathrm{Cu}(\mathrm{RN}-X a n t p h o s)\left(\mathrm{N}^{\wedge} \mathrm{N}\right)\right]\left[\mathrm{PF}_{6}\right]$ in Light-Emitting Electrochemical Cells. Adv. Opt. Mater. 2020, 8, 1901689. [CrossRef]

31. Igawa, S.; Hashimoto, M.; Kawata, I.; Yashima, M.; Hoshino, M.; Osawa, M. Highly Efficient Green Organic Light-Emitting Diodes Containing Luminescent Tetrahedral Copper(I) Complexes. J. Mater. Chem. C 2013, 1, 542-551. [CrossRef]

32. Osawa, M.; Kawata, I.; Ishii, R.; Igawa, S.; Hashimoto, M.; Hoshino, M. Application of neutral d ${ }^{10}$ coinage metal complexes with an anionic bidentate ligand in delayed fluorescence-type organic light-emitting diodes. J. Mater. Chem. C 2013, 1, 4375-4383. [CrossRef]

33. Uoyama, H.; Goushi, K.; Shizu, K.; Nomura, H.; Adachi, C. Highly efficient organic light-emitting diodes from delayed fluorescence. Nature 2012, 492, 234-238. [CrossRef]

34. Hosokai, T.; Matsuzaki, H.; Nakanotani, H.; Tokumaru, K.; Tsutsui, T.; Furube, A.; Nasu, K.; Nomura, H.; Yahiro, M.; Adachi, C. Evidence and mechanism of efficient thermally activated delayed fluorescence promoted by delocalized excited states. Sci. Adv. 2017, 3, e1603282. [CrossRef]

35. Noda, H.; Nakanotani, H.; Adachi, C. Excited state engineering for efficient reverse intersystem crossing. Sci. Adv. 2018, 4, eaao6910. [CrossRef] [PubMed]

36. Li, X.; Shi, Y.-Z.; Wang, K.; Zhang, M.; Zheng, C.-J.; Sun, D.-M.; Dai, G.-L.; Fan, X.-C.; Wang, D.-Q.; Liu, W.; et al. Thermally Activated Delayed Fluorescence Carbonyl Derivatives for Organic Light-Emitting Diodes with Extremely Narrow Full Width at Half-Maximum. ACS Appl. Mater. Interfaces 2019, 11, 13472-13480. [CrossRef] [PubMed]

37. Nakanotan, H.; Tsuchiya, Y.; Adachi, C. Thermally-activated Delayed Fluorescence for Light-emitting Devices. Chem. Lett. 2021, 50, 938-948. [CrossRef]

38. Chan, C.-Y.; Tanaka, M.; Lee, Y.-T.; Wong, Y.-W.; Nakanotani, H.; Hatakeyama, T.; Adachi, C. Stable pure-blue hyperfluorescence organic light-emitting diodes with high-efficiency and narrow emission. Nat. Photonics 2021, 15, 203-207. [CrossRef]

39. Sharma, N.; Wong, M.Y.; Samuel, I.D.W.; Zysman-Colman, E. Solution-Processed TADF Materials and Devices Based on Organic Emitters. In Highly Efficient OLEDs—Materials Based on Thermally Activated Delayed Fluorescence; Yersin, H., Ed.; Wiley-VCH: Weinheim, Germany, 2019; pp. 501-541.

40. Wong, M.Y.; Zysman-Colman, E. Purely Organic Thermally Activated Delayed Fluorescence Materials for Organic Light-Emitting Diodes. Adv. Mater. 2017, 29, 1605444. [CrossRef] [PubMed]

41. Chen, X.-K.; Kim, D.; Brédas, J.-L. Thermally Activated Delayed Fluorescence (TADF) Path toward Efficient Electroluminescence in Purely Organic Materials: Molecular Level Insight. Acc. Chem. Res. 2018, 51, 2215-2224. [CrossRef] [PubMed]

42. Sommer, G.A.; Mataranga-Popa, L.N.; Czerwieniec, R.; Hofbeck, T.; Homeier, H.H.H.; Müller, T.J.J.; Yersin, H. Design of Conformationally Distorted Donor-Acceptor Dyads Showing Efficient Thermally Activated Delayed Fluorescence. J. Phys. Chem. Lett. 2018, 9, 3692-3697. [CrossRef] [PubMed]

43. Schmidt, T.D.; Brütting, W. Efficiency Enhancement of Organic Light-Emitting Diodes Exhibiting Delayed Fluorescence and Nonisotropic Emitter Orientation. In Highly Efficient OLEDs_Materials Based on Thermally Activated Delayed Fluorescence; Yersin, H., Ed.; Wiley-VCH: Weinheim, Germany, 2019; pp. 199-228.

44. Liu, Y.; Li, C.; Ren, Z.; Yan, S.; Bryce, M.R. All-organic thermally activated delayed fluorescence materials for organic light-emitting diodes. Nat. Rev. Mater. 2018, 3, 18020. [CrossRef]

45. Yersin, H.; Mataranga-Popa, L.; Czerwieniec, R.; Dovbii, Y. Design of a New Mechanism beyond Thermally Activated Delayed Fluorescence toward Fourth Generation Organic Light Emitting Diodes. Chem. Mater. 2019, 31, 6110-6116. [CrossRef]

46. Yersin, H.; Mataranga-Popa, L.; Li, S.-W.; Czerwieniec, R. Design strategies for materials showing thermally activated delayed fluorescence and beyond: Towards the fourth-generation OLED mechanism. J. Soc. Inf. Disp. 2018, 26, 194-199. [CrossRef]

47. Zink, D.M.; Bächle, M.; Baumann, T.; Nieger, M.; Kühn, M.; Wang, C.; Klopper, W.; Monkowius, U.; Hofbeck, T.; Yersin, H.; et al. Synthesis, structure, and characterization of dinuclear copper(I) halide complexes with $\mathrm{P}^{\wedge} \mathrm{N}$ ligands featuring exciting photoluminescence properties. Inorg. Chem. 2013, 52, 2292-2305. [CrossRef]

48. Hofbeck, T.; Monkowius, U.; Yersin, H. Highly efficient luminescence of $\mathrm{Cu}(\mathrm{I})$ compounds: Thermally activated delayed fluorescence combined with short-lived phosphorescence. J. Am. Chem. Soc. 2015, 137, 399-404. [CrossRef]

49. Hofbeck, T.; Niehaus, T.A.; Fleck, M.; Monkowius, U.; Yersin, H. P $\cap$ N Bridged Cu(I) Dimers Featuring Both TADF and Phosphorescence. From Overview towards Detailed Case Study of the Excited Singlet and Triplet States. Molecules 2021, $26,3415$. [CrossRef] 
50. Schinabeck, A.; Leitl, M.J.; Yersin, H. Dinuclear Cu(I) Complex with Combined Bright TADF and Phosphorescence. Zero-Field Splitting and Spin-Lattice Relaxation Effects of the Triplet State. J. Phys. Chem. Lett. 2018, 9, 2848-2856. [CrossRef]

51. Schinabeck, A.; Rau, N.; Klein, M.; Sundermeyer, J.; Yersin, H. Deep blue emitting Cu(I) tripod complexes. Design of high quantum yield materials showing TADF-assisted phosphorescence. Dalton Trans. 2018, 47, 17067-17076. [CrossRef]

52. Leitl, M.J.; Küchle, F.-R.; Mayer, H.A.; Wesemann, L.; Yersin, H. Brightly blue and green emitting Cu(I) dimers for singlet harvesting in OLEDs. J. Phys. Chem. A 2013, 117, 11823-11836. [CrossRef]

53. Gneuß, T.; Leitl, M.J.; Finger, L.H.; Rau, N.; Yersin, H.; Sundermeyer, J. A new class of luminescent Cu(I) complexes with tripodal ligands-TADF emitters for the yellow to red color range. Dalton Trans. 2015, 44, 8506-8520. [CrossRef] [PubMed]

54. Chen, X.-L.; Yu, R.; Wu, X.-Y.; Liang, D.; Jia, J.-H.; Lu, C.-Z. A strongly greenish-blue-emitting $\mathrm{Cu}_{4} \mathrm{Cl}_{4}$ cluster with an efficient spin-orbit coupling (SOC): Fast phosphorescence versus thermally activated delayed fluorescence. Chem. Commun. 2016, 52, 6288-6291. [CrossRef] [PubMed]

55. Baranov, A.Y.; Berezin, A.S.; Samsonenko, D.G.; Mazur, A.S.; Tolstoy, P.M.; Plyusnin, V.F.; Kolesnikov, I.E.; Artem'ev, A.V. New $\mathrm{Cu}(\mathrm{I})$ halide complexes showing TADF combined with room temperature phosphorescence: The balance tuned by halogens. Dalton Trans. 2020, 49, 3155-3163. [CrossRef]

56. Li, C.; Li, W.; Henwood, A.F.; Hall, D.; Cordes, D.B.; Slawin, A.M.Z.; Lemaur, V.; Olivier, Y.; Samuel, I.D.W.; Zysman-Colman, E. Luminescent Dinuclear Copper(I) Complexes Bearing an Imidazolylpyrimidine Bridging Ligand. Inorg. Chem. 2020, 59, 1477214784. [CrossRef]

57. Hobbollahi, E.; List, M.; Hupp, B.; Mohr, F.; Berger, R.J.F.; Steffen, A.; Monkowius, U. Highly efficient cold-white light emission in a $\mathrm{Au}_{2} \mathrm{CuCl}_{2}(\mathrm{P} \cap \mathrm{N})_{2} \mathrm{PF}_{6}$ type salt. Dalton Trans. 2017, 46, 3438-3442. [CrossRef] [PubMed]

58. Chen, K.; Shearer, J.; Catalano, V.J. Subtle Modulation of $\mathrm{Cu}_{4} \mathrm{X}_{4} \mathrm{~L}_{2}$ Phosphine Cluster Cores Leads to Changes in Luminescence. Inorg. Chem. 2015, 54, 6245-6256. [CrossRef]

59. Artem'ev, A.V.; Shafikov, M.Z.; Schinabeck, A.; Antonova, O.V.; Berezin, A.S.; Bagryanskaya, I.Y.; Plusnin, P.E.; Yersin, H. Sky-blue thermally activated delayed fluorescence (TADF) based on $\mathrm{Ag}(\mathrm{I})$ complexes: Strong solvation-induced emission enhancement. Inorg. Chem. Front. 2019, 6, 3168-3176. [CrossRef]

60. Artem'ev, A.V.; Davydova, M.P.; Berezin, A.S.; Ryzhikov, M.R.; Samsonenko, D.G. Dicopper(I) Paddle-Wheel Complexes with Thermally Activated Delayed Fluorescence Adjusted by Ancillary Ligands. Inorg. Chem. 2020, 59, 10699-10706. [CrossRef]

61. Davydova, M.P.; Rakhmanova, M.I.; Bagryanskaya, I.Y.; Brylev, K.A.; Artem'ev, A.V. A 1D Coordination Polymer Based on CuI and 2-(Diphenylphosphino)Pyrimidine: Synthesis, Structure and Luminescent Properties. J. Struct. Chem. 2020, 61, 894-898. [CrossRef]

62. Stoïanov, A.; Gourlaouen, C.; Vela, S.; Daniel, C. Luminescent Dinuclear Copper(I) Complexes as Potential Thermally Activated Delayed Fluorescence (TADF) Emitters: A Theoretical Study. J. Phys. Chem. A 2018, 122, 1413-1421. [CrossRef]

63. Monkowius, U.; Hofbeck, T.; Yersin, H. Singulett-Harvesting mit Zweikernigen Kupfer(I)-Komplexen für Opto-Elektronische Vorrichtungen. German Patent DE102011080240 A1, 2 August 2013.

64. Wallesch, M.; Verma, A.; Fléchon, C.; Flügge, H.; Zink, D.M.; Seifermann, S.M.; Navarro, J.M.; Vitova, T.; Göttlicher, J.; Steininger, R.; et al. Towards Printed Organic Light-EmittingDevices: A Solution-Stable, Highly Soluble Cu ${ }^{\mathrm{I}}$-NHetPHOS Complex for Inkjet Processing. Chemistry 2016, 22, 16400-16405. [CrossRef]

65. Busch, J.M.; Koshelev, D.S.; Vashchenko, A.A.; Fuhr, O.; Nieger, M.; Utochnikova, V.V.; Bräse, S. Various Structural Design Modifications: Para-Substituted Diphenylphosphinopyridine Bridged Cu(I) Complexes in Organic Light-Emitting Diodes. Inorg. Chem. 2021, 60, 2315-2332. [CrossRef] [PubMed]

66. Cheng, G.; Chow, P.-K.; Kui, S.C.F.; Kwok, C.-C.; Che, C.-M. High-Efficiency polymer light-emitting devices with robust phosphorescent platinum(II) emitters containing tetradentate dianionic $\mathrm{O}^{\wedge} \mathrm{N}^{\wedge} \mathrm{C}^{\wedge} \mathrm{N}$ ligands. Adv. Mater. 2013, 25, 6765-6770. [CrossRef] [PubMed]

67. Yersin, H.; Rausch, A.F.; Czerwieniec, R.; Hofbeck, T.; Fischer, T. The triplet state of organo-transition metal compounds. Triplet harvesting and singlet harvesting for efficient OLEDs. Coord. Chem. Rev. 2011, 255, 2622-2652. [CrossRef]

68. Siddique, Z.A.; Yamamoto, Y.; Ohno, T.; Nozaki, K. Structure-dependent photophysical properties of singlet and triplet metal-toligand charge transfer states in copper(I) bis(diimine) compounds. Inorg. Chem. 2003, 42, 6366-6378. [CrossRef]

69. Iwamura, M.; Takeuchi, S.; Tahara, T. Real-time observation of the photoinduced structural change of bis(2,9-dimethyl-1,10phenanthroline)copper(I) by femtosecond fluorescence spectroscopy: A realistic potential curve of the Jahn-Teller distortion. J. Am. Chem. Soc. 2007, 129, 5248-5256. [CrossRef]

70. Chen, L.X.; Shaw, G.B.; Novozhilova, I.; Liu, T.; Jennings, G.; Attenkofer, K.; Meyer, G.J.; Coppens, P. MLCT state structure and dynamics of a copper(I) diimine complex characterized by pump-probe X-ray and laser spectroscopies and DFT calculations. J. Am. Chem. Soc. 2003, 125, 7022-7034. [CrossRef]

71. Turro, N.J. Modern Molecular Photochemistry of Organic Molecules; Benjamin/Cummings: Melon Park, CA, USA, 1978.

72. Zhang, Q.; Komino, T.; Huang, S.; Matsunami, S.; Goushi, K.; Adachi, C. Triplet Exciton Confinement in Green Organic Light-Emitting Diodes Containing Luminescent Charge-Transfer Cu(I) Complexes. Adv. Funct. Mater. 2012, 22, $2327-2336$. [CrossRef]

73. Teng, T.; Xiong, J.; Cheng, G.; Zhou, C.; Lv, X.; Li, K. Solution-Processed OLEDs Based on Thermally Activated Delayed Fluorescence Copper(I) Complexes with Intraligand Charge-Transfer Excited State. Molecules 2021, 26, 1125. [CrossRef] 
74. Klein, M.; Rau, N.; Wende, M.; Sundermeyer, J.; Cheng, G.; Che, C.-M.; Schinabeck, A.; Yersin, H. Cu(I) and Ag(I) Complexes with a New Type of Rigid Tridentate N,P,P-Ligand for Thermally Activated Delayed Fluorescence and OLEDs with High External Quantum Efficiency. Chem. Mater. 2020, 32, 10365-10382. [CrossRef]

75. Son, K.S.; Yahiro, M.; Imai, T.; Yoshizaki, H.; Adachi, C. Analyzing Bipolar Carrier Transport Characteristics of DiarylaminoSubstituted Heterocyclic Compounds in Organic Light-Emitting Diodes by Probing Electroluminescence Spectra. Chem. Mater. 2008, 20, 4439-4446. [CrossRef]

76. Anthopoulos, T.D.; Markham, J.P.J.; Namdas, E.B.; Samuel, I.D.W. Highly effcient single-layer dendrimer light-emitting diodes with balanced charge transport. Appl. Phys. Lett. 2003, 82, 4824-4826. [CrossRef]

77. Sharma, G.; Hashmi, S.Z.; Kuma, U.; Kattayat, S.; Ahmad, M.A.; Kumar, S.; Dalela, S.; Alvi, P.A. Optical and electronic characteristics of ITO/NPB/Alq3:DCJTB/ Alq3/Ag heterostructure based organic light emitting diode. Optik 2020, $223,165572$. [CrossRef]

78. Sworakowski, J.; Lipiński, J.; Janus, K. On the reliability of determination of energies of HOMO and LUMO levels in organic semiconductors from electrochemical measurements. A simple picture based on the electrostatic model. Org. Electron. 2016, 33, 300-310. [CrossRef] 